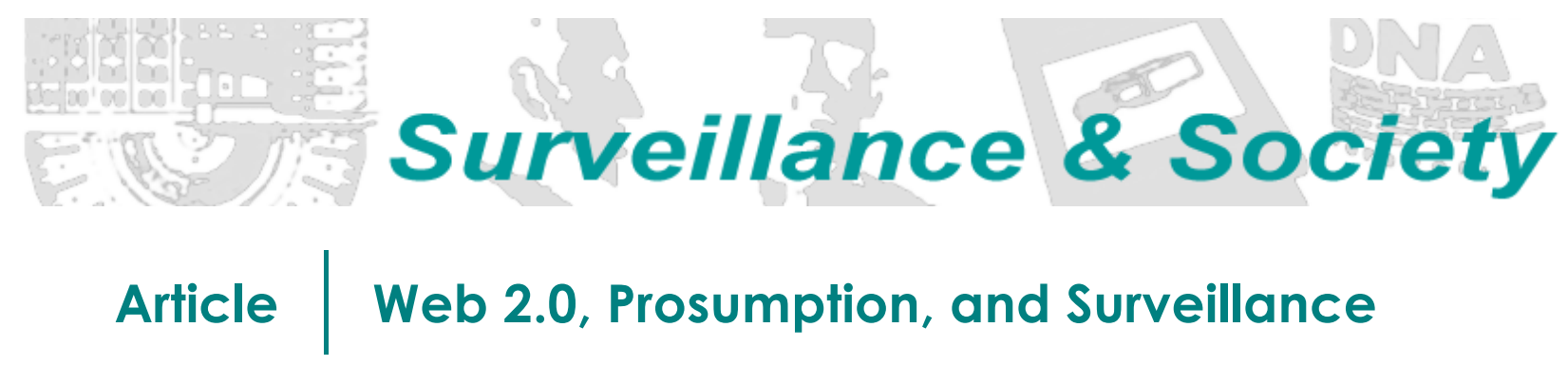

\title{
Christian Fuchs
}

Uppsala University, Sweden. christian.fuchs@uti.at

\begin{abstract}
"Web 2.0" platforms such as YouTube, MySpace, Facebook, Flickr, and Twitter that focus on data sharing, communication, community, and co-production have become very popular. It is therefore important to understand the economic organization of these platforms. The discussion of surveillance in web 2.0 is important because such platforms collect huge amounts of personal data in order to work. In this paper, first the example of Google Buzz is discussed. Next, a model that conceptualizes the cycle of capital accumulation and distinguishes between production and circulation of capital is introduced, after which the role of surveillance in web 2.0 is outlined based on the cycle of capital accumulation. The notions of the Internet prosumer commodity and web 2.0 surveillance are introduced in order to characterize the relationship of production, consumption, and surveillance on web 2.0.
\end{abstract}

\section{Introduction}

Many observers claim that the Internet in general and the world wide web in particular have been transformed in the past years from a system that is primarily oriented on information provision into a system that is more oriented towards communication, user-generated content, data sharing, and community building (see, for example, Castells 2009; O'Reilly 2005; Tapscott and Williams 2006). The notions of 'web 2.0', 'social software', and 'social network(ing) sites' have emerged in this context. Web platforms such as Wikipedia, MySpace, Facebook, YouTube, Google, Blogger, Rapidshare, Wordpress, Hi5, Flickr, Photobucket, Orkut, Skyrock, Twitter, YouPorn, PornHub, Youku, Orkut, Redtube, Friendster, Adultfriendfinder, Megavideo, Tagged, Tube8, Mediafire, Megaupload, Mixi, Livejournal, LinkedIn, Netlog, ThePirateBay, Orkut, XVideos, Metacafe, Digg, StudiVZ, etc. are said to be typical for this transformation of the Internet.

The best known definition of 'web 2.0' has been given by Tim O'Reilly (2005):

Web 2.0 is the network as platform, spanning all connected devices; Web 2.0 applications are those that make the most of the intrinsic advantages of that platform: delivering software as a continually-updated service that gets better the more people use it, consuming and remixing data from multiple sources, including individual users, while providing their own data and services in a form that allows remixing by others, creating network effects through an "architecture of participation", and going beyond the page metaphor of Web 1.0 to deliver rich user experiences. 
Blogs, wikis, file sharing platforms, and social networking platforms are some of the techno-social systems that shape users' Internet experiences in contemporary society. Scholars, the media, and parts of the public claim that the Internet has become more social, more participatory, and more democratic (see Fuchs 2010b). These claims might be overdrawn and techno-optimistic ideologies, seeing that e-mail technology was created in the early 1970 s and has for a long time since been the most popular and widely used Internet technology, which shows that the Internet was social and communicative right from its outset. Therefore the claims about "web 2.0" should be more modest. Many web 2.0 sites combine older applications such as forums, guest books, e-mail, multimedia, and hypertext in one user-friendly platform, which increases the appeal and ease-of-use and so supports increased usage. Increased bandwidth and cheaper production technologies (such as digital cameras) now allow easy, fast, and cheap transmission and sharing of audio and video files, and has resulted in increased popularity of user-generated content. The discussion of surveillance in web 2.0 is important because such platforms collect huge amounts of personal data in order to work.

Although there is a hype about web 2.0, there is a certain truth in the claim that the Internet and the world wide web have changed: empirical analysis shows that, on the one hand, information provision is still the most important function of the web, but that, on the other hand, co-operative functions of the web (community building, data sharing, collaborative information production) have become more important (Fuchs 2010b). The notion of web 2.0 might therefore be used for characterizing these changes, though at the same time there are important continuities in the development of the web (Fuchs 2010b; Fuchs, Hofkirchner, Schafranek, Raffl, Sandoval and Bichler 2010).

This paper tries to give an answer to the question: how do web 2.0 corporations make profit? To do so, I discuss foundations of the political economy of web 2.0. In particular, the role of prosumption and surveillance will be outlined. First, I discuss the example of Google Buzz (section 2). Then, I introduce some foundations of critical political economy (section 3), which are related to the notions of surveillance and prosumption (section 4). Finally, some conclusions are drawn (section 5).

This paper is based on a political economy approach. Political economy focuses on the analysis of the inner constitution and dynamics of the economic system. It is political economy because it sees political interests at work in the modern economy. In critical political economy, these interests are conceived as contradictory class interests. Critique of political economy aims to show the limitations, contradictions, and problems of the capitalist economy; it questions the legitimacy and logic of academic approaches that conceive capitalist phenomena (such as the commodity, exchange value, profit, money, capital, the division of labour, etc) as universal and not as historically contingent and changeable, and it questions the modes of thinking that postulate the endlessness and reification of existing reality (ideology critique).

\section{Google Buzz: An Example for the Web 2.0 Political Economy of Surveillance}

I start with an example that shows the problems of web 2.0 surveillance: Google Buzz. In February 2010, Google introduced a new social networking service called Buzz. Buzz is directly connected to GMail, Google's webmail-platform. Google's introduction of Buzz is an attempt to gain importance in the social networking sites-market that has been dominated by Facebook and Twitter. In February 2010, Facebook was ranked number 2 and Twitter number 12 in the list of the most accessed web platforms, whereas Google's own social networking platform Orkut, which is only very popular in Brazil, was at number $52^{1}$. Popular social networking platforms attract millions of users, who upload and share personal information that provides data about their consumption preferences. Therefore commercial social networking sites are keen on storing, analyzing, and selling individual and aggregated data about user preferences and user behaviour to advertising clients in order to accumulate capital (Fernback and Papacharissi 2007; Fuchs

\footnotetext{
${ }^{1}$ Data source: http://alexa.com, search term "the top 500 sites on the web”, accessed February 14, 2010.
} 
2009). Google is itself a main player in the business of online advertising. One can therefore assume that Google considers Facebook, Twitter, and other platforms that attract many users, as competitors, and that as a result of this competitive situation Google has introduced Buzz. In 2009, GMail had approximately 150 million users (Tech 24 Hours 2009), which explains that Google integrated Buzz into GMail in order to start from a solid foundation of potential users.

Buzz supports the following communicative functions: creating postings that are shared with contacts; sharing of images and videos; commenting on and evaluating others' Buzz posts; forwarding of Twitter messages to a Buzz account; linking and integrating images uploaded to Flickr or Picasa, videos uploaded to YouTube, and posts generated on Blogger; and use of Buzz via mobile phones. Buzz messages can either be presented publicly or only to selected groups of followers. Each user's Buzz profile has a list of followers and users can select which Buzz accounts they want to follow. Buzz mobile phone messages include geo-tags that display the current location of users. Buzz posts of users who are geographically located nearby a user and information about nearby sites, shops, restaurants, etc can be displayed on mobile phones. Buzz also recommends postings by other users.

In December 2009, Google's CEO Eric Schmidt commented on online privacy: "If you have something that you do not want anyone to know, maybe you should not be doing it in the first place" (YouTube 2009). Google's Privacy Policy states that it is allowed to "process personal information on behalf of and according to the instructions of a third party, such as our advertising partners". It "may share with third parties certain pieces of aggregated, non-personal information, such as the number of users who searched for a particular term, for example, or how many users clicked on a particular advertisement". "Google uses the DoubleClick advertising cookie on AdSense partner sites and certain Google services to help advertisers and publishers serve and manage ads across the web" (Google 2010a). There is only an opt-out from DoubleClick, which means that Google automatically collects information about users on affiliated websites as long as they do not opt out. The privacy policy shows that Google's economic aim is to accumulate profit by commodifying user data. Schmidt's statement is an indication that Google, or at least its most important managers and shareholders, do not value privacy very highly. It implies that he thinks that in the online world, all uploaded information and personal data should be available publicly and should be usable by corporations for economic ends.

When first installing Buzz, the application automatically generated a list of followers for each user based on the most frequent GMail mail contacts. The standard setting was to automatically make this list of followers publicly visible. This design move resulted in heavy criticism of Google in the days following the launch of Buzz. Users and civil rights advocates argued that Buzz threatens the privacy of users and makes contacts available in public that users might want to keep private. Google reacted to public criticism (see Jackson 2010; Huffington Post 2010) and changed some of the standard settings of Buzz on February 13, 2010. Some changes were made to the auto-follow option, so that now a dialogue is displayed that shows which users Buzz suggests as followers (Jackson 2010); however, Buzz still creates this list of suggested followers automatically, which does not make this solution an opt-in version of the follow feature. Google also said that Buzz would no longer automatically connect publicly available Picasa and Google Reader items to the application. Furthermore, an options menu was announced that allows users to hide their contact list from their public Google profiles (Jackson 2010). The problem here again is this was planned as an opt-out solution, not as an opt-in option. From a privacy-enhancing perspective, opt-in solutions are preferable to opt-out solutions because they give users more control over what applications are allowed to do with their data. However, it is clear that opt-in solutions are rather unpopular design options for many Internet corporations because they tend to reduce the number of potential users that are subject to advertising-oriented data surveillance.

At the Google Buzz launch event on February 9, 2010, the presenters were keen to stress the advantages that Buzz poses for users. Bradley Horwitz, Google vice president of product marketing, spoke of Buzz as 
"a Google approach to sharing" and a tool that will "help you manage your attention better" (YouTube 2010). There was no talk about potential disadvantages. During the question and answer section of the event, the first question that came about was about privacy issues, to which Buzz product manager Todd Jackson answered: "There is a lot of controls [sic] in there for users. [...] There are ways to control the settings you are revealing to other people" (ibid). Four days later, following public discussion about the surveillance and privacy threats of Buzz, Google sounded much less optimistic. On the Google GMail blog, Jackson wrote: "We've heard your feedback loud and clear, and since we launched Google Buzz four days ago, we've been working around the clock to address the concerns you've raised" (Jackson 2010).

Google's economic strategy is to gather data about users that utilize different Google applications in different everyday situations. The more everyday situations can be supported by Google applications, the more time users will spend online with Google, so that more user data will be available to Google, which allows the company to better analyze usage and consumer behaviour. As a result, more and more precise user data and aggregated data can be sold to advertising clients who, armed with information about potential consumption choices, provide users with personalized advertising that targets them in all of these everyday situations. Felix Stalder and Christine Mayer (2009) have analyzed the data different Google applications collect and conclude that Google conducts surveillance of users as knowledge persons, social persons, and physical persons. The introduction of ever more applications does primarily serve economic ends that are realized by large-scale user surveillance. As more and more people access the Internet from their mobile phones, the number of times and the time-spans users are online, as well as the number of access points and situations in which users are online, increase. Therefore, supplying applications that are attractive for users in all of these circumstances (e.g. waiting for the bus, travelling on a train or aeroplane, going to a restaurant, concert, or movie, visiting friends, or attending a business meeting), promises that users spend more time online with applications supplied by specific companies like Google, which allows these companies to present more advertisements that are more individually targeted to users, which in turn promises more profit for the companies. We can therefore say that there is a strong economic incentive for Google's and other companies' introduction of new Internet- and mobile Internet-applications.

Google Buzz is part of Google's empire of economic surveillance. It gathers information about user behaviour and user interests in order to store, assess, and sell this data to advertising clients. These surveillance practices are legally guaranteed by the Buzz privacy policy, which says for example:

When you use Google Buzz, we may record information about your use of the product, such as the posts that you like or comment on and the other users who you communicate with. This is to provide you with a better experience on Buzz and other Google services and to improve the quality of Google services. [...] If you use Google Buzz on a mobile device and choose to view 'nearby' posts, your location will be collected by Google.

(Google 2010b).

Google uses DoubleClick - a commercial advertising server that collects and networks data about usage behaviour on various websites - to network the data it holds about its users with data about these users' browsing and usage behaviour on other web platforms. DoubleClick has been owned by Google since 2007 and, in addition to collecting and networking data about usage behaviour, sells this data, and helps providing targeted advertising. There is only an opt-out option from this form of networked economic surveillance. Opt-out options are always rather unlikely to be used because in many cases they are hidden inside of long privacy and usage terms and are therefore only really accessible to knowledgeable users. Many Internet corporations avoid opt-in advertising solutions because such mechanisms drastically reduce the potential number of users participating in advertising. The Google privacy policy says in this context:

Google uses the DoubleClick advertising cookie on AdSense partner sites and certain Google services to help advertisers and publishers serve and manage ads across the web. 
You can view, edit, and manage your ads preferences associated with this cookie by accessing the Ads Preferences Manager. In addition, you may choose to opt out of the DoubleClick cookie at any time by using DoubleClick's opt-out cookie.

(Google 2010a).

Google's online product advertising for Buzz says:

The first thing we all do when we find something interesting is share it. More and more of this kind of sharing takes place online. Google Buzz is a new way to share updates, photos, videos, and more. [...] When you are out in the real world, you usually want to say something about where you are. Buzz makes this easy.

(Google 2010c).

Sharing information with friends and to a certain extent with the public is surely an important feature of everyday communication that allows humans to stay in touch and to make new contacts. But Google only presents potential advantages of Buzz and does not say a single word about potential disadvantages. Do people really want to share vast amounts of private data and location data not only with their friends, but also with Google? Can Google be considered as a friend of all humans, or doesn't it rather accumulate power that can also cause great harm to humans? Do people really always want to tell others where they currently are? Are people really interested in sharing their location data not only with selected friends, but also with Google? It is natural corporate behaviour that Google only presents potential advantages of its applications in its marketing videos, adverts, and events. But by doing so, it creates a one-dimensional picture of online reality that conveys the impression that we live in a world without power structures, in which all humans always benefit from corporate practices. Yet the recent great financial crisis has made clear to many citizens that corporations cannot always be trusted and are prone to act in ways that do not benefit all, but instead only a small group of investors.

Buzz is not the only example of Google-enhanced surveillance. Google has developed Goggles, an imagerecognition software that identifies objects that people take pictures of by mapping these objects with Google's image database and then provides information about these objects. If this application were linked to image data about humans, it would allow people to identify and obtain information about humans who they see on the street by taking a picture of them and linking this image to Google in real time. This would allow humans to intrude the privacy of others in public spaces through personal identification and it would additionally allow Google to gather, assess, provide, and potentially sell real time data about the physical location of millions of people.

Why is data surveillance for economic surveillance by Google applications such as Buzz problematic? One could argue that Google provides a free service to users and that in return it should be allowed to access, store, analyze, and use personal data and Internet usage behaviour. But the problem is that the power relations between Google and its users are not symmetrical. In December 2008, Google controlled $57 \%$ of the online advertising market (Attributor 2008). A Google monopoly in online advertising poses several threats (for a general account of the threats of information monopolies see Fuchs 2008, 164-171):

Ideological power threat: Online advertising presents certain realities as important to users and leaves out those realities that are non-corporate in character or that are produced by actors that do not have enough capital in order to purchase online advertisements. An online advertising monopoly therefore advances one-dimensional views of reality.

Political power threat: In modern society, money is a form of influence on political power. The concentration of online advertising therefore gives Google huge political power. 
Control of labour standards and prices: An online advertising monopoly holds the power to set industrywide labour standards and prices. This can pose disadvantages for workers and consumers.

Economic centralization threat: An economic monopoly controls large market shares and thereby deprives other actors of economic opportunities.

Surveillance threat: Targeted online advertising is based on the collection of vast amounts of personal user data and usage behaviour that is then stored, analyzed, and passed on to advertising customers. Modern societies are stratified, which means that certain groups and individuals compete with others for the control of resources, consider others as their opponents, benefit from certain circumstances at the expense of others, and so forth. As a result, information about personal preferences and individual behaviour can cause harm to individuals if it gets into the hand of their opponents or others who might have an interest in harming them. Large-scale data gathering and surveillance in a society based on the principle of competition poses certain threats to the well-being of all citizens. Therefore, special privacy protection mechanisms are needed. All large collections of data pose the threat of being accessed by individuals who want to harm others. If such collections are owned privately, then access to data might be sold because there is an economic interest in accumulating money. Humans who live in modern societies have an inherent interest in controlling which personal data about them is stored and is available to whom because they are facing systemic threats of being harmed by others. Under our current modern circumstances, large collections of personal information pose the threat of harm to individuals because their foes, opponents, or rivals in private or professional life can potentially gain access to such data. Since $9 / 11$, there has been an extension and intensification of state surveillance based on the argument that security from terrorism is more important than privacy. But state surveillance is prone to failure, and the access of state institutions to large online collections about citizens (as for example that enabled by the USA PATRIOT Act) not only poses the possibility of detecting terrorists, but also the threat that a large number of citizens be considered as potential criminals or terrorists without having committed any crimes, as well as the threat that the state obtains a huge amount of information about the private lives of citizens that the latter consider worth protecting (such as political views, voting decisions, sexual preferences and relationships, and friendship statuses).

Overall, the introduction of Google Buzz shows that there is an antagonism between privacy protection and economic surveillance interests on the Internet nowadays that is dominated by commercial interests. It might be time to think more about strengthening alternative Internet platforms and the potentials for constructing an alternative Internet (Atton 2004). For Atton, the model of an alternative Internet is Indymedia, which is "opposed to hierarchical, elite-centred notions of journalism as business" and places "power into the hands of those who are more intimately involved in those stories" so that "activists become journalists" (Atton 2004, 26f). Atton shows that in 2002 after 9/11 there was a distinct shift away from open publishing and direct-action news at Indymedia towards instead the publication of selected mainstream reports and articles by left-wing intellectuals like Noam Chomsky. Atton sees this move positively as an opening up "beyond the faithful" (Atton 2004, 52). Overall, Atton argues for noncorporate Internet platforms that that engage in political criticism of capitalism and Internet platforms that make knowledge available for free (such as filesharing platforms) and thereby decommodify knowledge. He discusses examples that, for him, anticipate an alternative organization of the Internet.

\section{Foundations of the Critical Political Economy Approach}

"Contemporary surveillance must be understood in the light of changed circumstances, especially the growing centrality of consumption and the adoption of information technologies"

(Lyon 1994, 225). 
Capitalism has changed. In Marx's time, consumer surveillance and electronic surveillance were hardly important. Economic surveillance focused on the control of the production process. Nonetheless, the Marxian framework of political economy that describes the cycle of capital accumulation, can be used today for systematically locating forms of economic surveillance in the production and circulation process.

In the three volumes of Capital, Marx $(1867 ; 1885 ; 1894)$ analyzes the accumulation process of capital. This process, as described by Marx, is visualized in figure 1. Introducing some important categories that Marx employs can summarize this account.

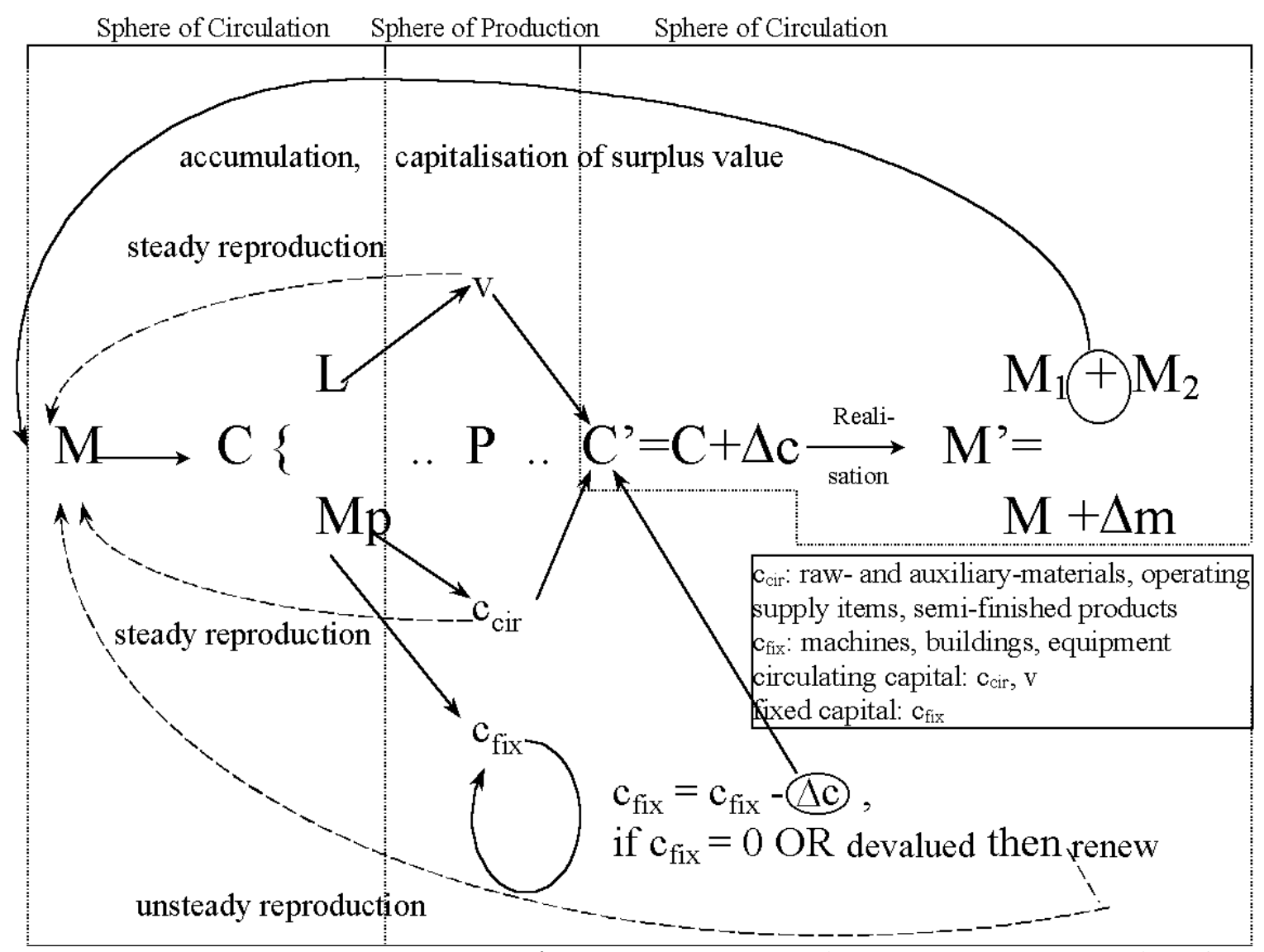

Figure 1: The accumulation/expanded reproduction of capital

Marx's theory is a labour theory of value, which draws its conclusion from the analysis of the total labour time that is needed for the production of goods. It is also a critique of value, which means that the forms that value takes in capitalism, and the practices and ideologies that are based on this form, are questioned. The value of a good is the total time that is needed for its production. The more value a good has, the longer its production takes. At the level of prices, this can be observed by the fact that labour-intensive goods are frequently more expensive than goods with low labour intensity. Marx argues that the cell form of capitalism is the commodity, goods that are exchanged in a certain quantitative relationship with money ( $\mathrm{x}$ amount of commodity $\mathrm{A}=\mathrm{y}$ units of money). He says that in societies based on the economic principle of exchange, goods have a use value and an exchange value. The use value is the qualitative aspect of a good; it is a utility that satisfies certain human needs. In exchange-based societies, humans can only get hold of such goods by exchanging other goods (such as money or their labour power) with the needed goods in certain quantitative relationships ( $\mathrm{x}$ commodity $\mathrm{A}=\mathrm{y}$ commodity $\mathrm{B}$ ). Concrete labour is a 
category that is used for describing the creation of the use value of a good by humans. Abstract labour is a category employed for signifying the creation of the value of a good, i.e. the objectified labour time needed for its production. Marx sees money as the general equivalent of exchange: it simplifies the exchange of commodities and is therefore a general commodity.

In the accumulation of capital, capitalists buy labour power and means of production (raw materials, technologies, etc) in order to produce new commodities that are sold with the expectation of making money profit that is partly reinvested. Marx distinguishes two spheres of capital accumulation: the circulation sphere and the sphere of production. In the circulation sphere, capital transforms its value form: first money $\mathrm{M}$ is transformed into commodities (from the standpoint of the capitalist as buyer), and the capitalist purchases the commodities' labour power L and means of production $\mathrm{Mp}$. M-C is based on the two purchases M-L and M-Mp. In capitalism, labour power is separated from the means of production, "the mass of the people, the workers, [..] come face to face with the non-workers, the former as nonowners, the latter as the owners, of these means of production" (Marx 1885, 116). This means that due to private property structures workers do not own the means of production, the products they produce, and the profit they generate; capitalists own these resources.

In the sphere of production, a new good is produced: the value of labour power and the value of the means of production are added to the product. Value takes on the form of productive capital P. The value form of labour is variable capital $\mathrm{v}$ (which can be observed as wages), and the value form of the means of production is constant capital c (which can be observed as the total price of the means of production/ producer goods).

That part of capital, therefore, which is turned into means of production, i.e. the raw material, the auxiliary material and the instruments of labour, does not undergo any quantitative alteration of value in the process of production. For this reason, I call it the constant part of capital, or more briefly, constant capital. On the other hand, that part of capital which is turned into labour-power does undergo an alteration of value in the process of production. It both reproduces the equivalent of its own value and produces an excess, a surplus-value, which may itself vary, and be more or less according to circumstances. This part of capital is continually being transformed from a constant into a variable magnitude. I therefore call it the variable part of capital, or more briefly, variable capital.

(Marx 1867, 317).

Constant capital consists of two parts: circulating constant capital $\mathrm{c}_{\text {cir }}$ (the value of the utilized raw materials, auxiliary materials, operating supply items and semi-finished products) and fixed constant capital $\mathrm{c}_{\mathrm{fix}}$ (the value of the utilized machines, buildings and equipment) (Marx 1885, Chapter 8). $\mathrm{c}_{\mathrm{cir}}$ and $\mathrm{v}$ together form circulating capital: they transfuse their value totally to the product and must be constantly renewed. $c_{\text {fix }}$ remains fixed in the production process for many turnovers of capital. The turnover time of capital is the sum of its circulation time and its production time (Marx 1885, 236). Circulation time is the time that capital takes to be transformed from its commodity form into the money form and later from its money form to its commodity form. Production time is the time that capital takes in the sphere of production.

Fixed constant capital decreases its value in each turnover of capital. Its value is decreased by the amount of $\Delta c$, which is a flexible value. Fixed constant capital like machinery does not create value and its value is never entirely transfused to capital at once. It is depreciated by wear and tear, non-usage, and moral depreciation (i.e. the emergence of new machinery with increased productivity).

A part of the capital value advanced is fixed in this form, which is determined by the function of the means of labour in the process. As a means of labour functions and is used 
up, one part of its value passes over to the product, while another part remains fixed in the means of labour and hence in the production process. The value fixed in this way steadily declines, until the means of labour is worn out and has therefore distributed its value, in a longer or shorter period, over the volume of products that has emerged from a series of continually repeated labour processes.

(Marx 1885, 237f).

In the sphere of production, capital stops its metamorphosis so that capital circulation comes to a halt. A new value $\mathrm{V}^{\prime}$ of the commodity is produced, which contains the value of the necessary constant and variable capital and surplus value $\Delta \mathrm{s}$ of the surplus product. Surplus value is generated by unpaid labour. Capitalists do not pay for the production of surplus, therefore the production of surplus value can be considered as a process of exploitation. The value $\mathrm{V}^{\prime}$ of the new commodity after production is $\mathrm{V}^{\prime}=\mathrm{c}+\mathrm{V}$ $+\mathrm{s}$. The commodity then leaves the sphere of production and again enters the circulation sphere, in which capital conducts its next metamorphosis: by being sold on the market, it is transformed from the commodity form back into the money form. Surplus value is thus realized in the form of money value. The initial money capital $M$ now takes on the form $M^{\prime}=M+\Delta m$, it has been increased by an increment $\Delta \mathrm{m}$. Accumulation of capital means that the produced surplus value is (partly) reinvested/capitalized. The end point of one process $\mathrm{M}^{\prime}$ becomes the starting point of a new accumulation process. One part of M', $\mathrm{M}_{1}$, is reinvested. Accumulation means the aggregation of capital by investment and exploitation through the capital circuit M-C..P...C'-M', in which the end product M' becomes a new starting point M. The total process makes up the dynamic character of capital. Capital is money that is permanently increasing due to the exploitation of surplus value.

Commodities are sold at prices that are higher than the investment costs so that money profit is generated. For Marx, one decisive quality of capital accumulation is that profit is an emergent property of production that is produced by labour but owned by the capitalists. Without labour no profit could be made, but workers are forced to enter class relations and to produce profit in order to survive, which enables capital (and thereby the capitalists) to appropriate surplus. The notion of exploited surplus value is the main concept of Marx's theory, by which he intends to show that capitalism is a class society. "The theory of surplus value is in consequence immediately the theory of exploitation" (Negri 1991, 74) and, one can add, the theory of class and, as a consequence, the political demand for a classless society.

Capital is not money, but money that is increased through accumulation, "money which begets money" (Marx 1867, 256). Marx argues that the value of labour power is the average amount of time that is needed for the production of goods that are necessary for survival (necessary labour time), which in capitalism is paid for by workers with their wages. Surplus labour time is all labour time that exceeds necessary labour time, remains unpaid, is appropriated for free by capitalists, and transformed into money profit.

\section{Capital accumulation, surveillance, and prosumption on web $\mathbf{2 . 0}$}

In this section, I will argue that the combination of surveillance and prosumption is at the heart of capital accumulation on web 2.0.

Following Ogura's (2006) and Gandy's (1993) argument that a common characteristic of surveillance is the management of population based on capitalism and/or the nation state, we can distinguish between economic and political surveillance as the two major forms of surveillance. Habermas (1981) has stressed that the most powerful structures in modern society are money and power, which relate to the economic and political realms. Individuals in everyday life may have the ambition to transform society, but in order to bring about change they have to overcome isolation and mobilize resources. Surveillance by nation states and corporations aims at controlling the behaviour of individuals and groups, i.e. the latter are forced to behave or not behave in certain ways because they know that their appearance, movements, 
location, or ideas are or could be watched by surveillance systems (Fuchs 2008, 267-277). In the case of political electronic surveillance, individuals are threatened by the potential exercise of organized violence (through the law) if they are seen by political actors, such as secret services or the police, to behave in certain ways that are undesired. In the case of economic electronic surveillance, individuals are threatened by the violence of the market that wants to force them to buy or produce certain commodities and help reproduce capitalist relations - this is done by gathering and using information on their economic behaviour with the help of electronic systems. In such forms of surveillance violence and heteronomy are the ultima ratio.

My approach is based on the critique of the political economy of media and information. Felicity Brown (2006) calls for a combination of the critical political economy of communication and surveillance studies. "The critical political economy of communication has a particularly important role in analyzing the mutually productive relationship between surveillance practices and the Internet. In particular, the intense monitoring of cyberspace by private corporations seeking information on consumer behaviour is worthy of critique" (Brown 2006, 10).

Marx highlights exploitation as the fundamental aspect of class in another passage where he says that "the driving motive and determining purpose of capitalist production" is "the greatest possible exploitation of labour-power by the capitalist" (Marx 1867, 449). He says that the proletariat is "a machine for the production of surplus-value", and capitalists are "a machine for the transformation of this surplus-value into surplus capital" (Marx 1867, 742). Whereas Marx in his time had to limit the notion of the proletariat to wage labour, it is today possible to conceive the proletariat in a much broader sense as all those who directly or indirectly produce surplus value and are thereby exploited by capital. This includes besides wage labour also houseworkers, the unemployed, the poor, migrants, retirees, students, precarious workers - and also the users of corporate web 2.0 platforms and other Internet sites and applications. Hardt and Negri (2004) use the term multitude for this multidimensional proletariat of the $21^{\text {st }}$ century.

Axel Bruns sees the rise of produsage - the "hybrid user/producer role which inextricably interweaves both forms of participation" (Bruns 2008, 21) - as the central characteristic of web 2.0. Alvin Toffler (1980) had introduced the notion of the prosumer in the early 1980s, which means the "progressive blurring of the line that separates producer from consumer" (Toffler 1980, 267). Toffler describes the age of prosumption as the arrival of a new form of economic and political democracy, self-determined work, labour autonomy, local production, and autonomous self-production. But he overlooks that prosumption is used for outsourcing work to users and consumers, who work without payment. Thereby corporations reduce their investment costs and labour costs, jobs are destroyed, and consumers who work for free are extremely exploited. They produce surplus value that is appropriated and turned into profit by corporations without paying wages. Notwithstanding Toffler's uncritical optimism, his notion of the "prosumer" describes important changes of media structures and practices and can therefore also be adopted for critical studies.

For Marx, the profit rate is the relation of profit to investment costs: $\mathrm{p}=\mathrm{s} /(\mathrm{c}+\mathrm{v})=$ surplus value / (constant capital (=fixed costs) + variable capital (=wages)). If Internet users become productive web 2.0 prosumers then, in terms of Marxian class theory, this means that they become productive labourers who produce surplus value and are exploited by capital because for Marx productive labour generates surplus. Therefore, in cases such as Google, YouTube, MySpace, or Facebook, exploitation of surplus value is not merely limited those who are employed by these corporations for programming, updating, and maintaining the soft- and hardware, performing marketing activities, and so on, but also extends to the users, and the prosumers that engage in the production of user-generated content. New media corporations do not (or hardly) pay the users for the production of content. One accumulation strategy is to give them free access to services and platforms, let them produce content, and to accumulate a large number of prosumers that are sold as a commodity to third-party advertisers. Not a product is sold to the users, but the users are sold 
as a commodity to advertisers. The more users a platform has, the higher the advertising rates can be set. The productive labour time that is exploited by capital involves, on the one hand, the labour time of the paid employees and, on the other hand, all of the time that is spent online by the users. For the first type of knowledge labour, new media corporations pay salaries. The second type of knowledge is produced completely for free. There are neither variable nor constant investment costs. The formula for the profit rate needs to be transformed for this accumulation strategy:

$\mathrm{p}=\mathrm{s} /(\mathrm{c}+\mathrm{v} 1+\mathrm{v} 2), \mathrm{s} \ldots$ surplus value, $\mathrm{c} \ldots$ constant capital, $\mathrm{v} 1 \ldots$ wages paid to fixed employees, $\mathrm{v} 2 \ldots$ wages paid to users

The typical situation is that $\mathrm{v} 2=>0$ and that $\mathrm{v} 2$ substitutes $\mathrm{v} 1$. If the production of content and the time spent online were carried out by paid employees, the variable costs would rise and profits would therefore decrease. This shows that prosumers in a capitalist society can be interpreted as the outsourcing of productive labour to users who work completely for free and help maximizing the rate of exploitation $(\mathrm{e}=$ $\mathrm{s} / \mathrm{v}$, = surplus value / variable capital) so that profits can be raised and new media capital may be accumulated. Again, this situation is one of infinite over-exploitation. Capitalist prosumption is an extreme form of exploitation, in which the prosumers work completely for free.

That surplus value generating labour is an emergent property of capitalist production means that production and accumulation will break down if this labour is withdrawn. It is an essential part of the capitalist production process. That prosumers conduct surplus-generating labour can also be seen by imagining what would happen if they would stop using platforms like YouTube, MySpace, and Facebook: the number of users would drop, advertisers would stop investments because no objects for their advertising messages and therefore no potential customers for their products could be found, the profits of the new media corporations would drop, and they would go bankrupt. If such activities were carried out on a large scale, a new economic crisis would arise. This thought experiment shows that users are essential for generating profit in the new media economy. Furthermore they produce and co-produce parts of the products, and therefore parts of the use value, exchange value, and surplus value that are objectified in these products.

Dallas Smythe (1981/2006) suggests that, in the case of media advertisement models, the audience is sold as a commodity to advertisers: "Because audience power is produced, sold, purchased and consumed, it commands a price and is a commodity. [...] You audience members contribute your unpaid work time and in exchange you receive the program material and the explicit advertisements" (Smythe 1981/2006, $233,238)$.

With the rise of user-generated content, free access social networking platforms, and other free access platforms that yield profit by online advertisement - a development subsumed under categories such as web 2.0, social software, and social networking sites - the web seems to come close to accumulation strategies employed by the capital on traditional mass media like TV or radio. The users who google data, upload or watch videos on YouTube, upload or browse personal images on Flickr, or accumulate friends with whom they exchange content or communicate online via social networking platforms like MySpace or Facebook, constitute an audience commodity that is sold to advertisers. The difference between the audience commodity on traditional mass media and on the Internet is that in the latter case the users are also content producers; the users engage in permanent creative activity, communication, community building, and content-production. That users are more active on the Internet than in the reception of TV or radio content is due to the decentralized structure of the Internet, which allows many-to-many communication. Due to the permanent activity of the recipients and their status as prosumers, we can say that, in the case of the Internet, the audience commodity is a prosumer commodity.

Mark Andrejevic has coined the notion of the digital enclosure (Andrejevic 2007), which means that interactive technologies generate "feedback about the transactions themselves" and that this feedback 
"becomes the property of private companies" (Andrejevic 2007, 3). Based on Marx and Smythe, we can argue that the contemporary Internet is a specific form of the digital enclosure that is based on the exploitation of prosumption: it is the realization of digital exploitation. Prosumers are digitally enclosed and digitally exploited.

The discussions about exploitation on the Internet are also connected to Italian autonomist Marxist discussions about immaterial labour and the commons. Maurizio Lazzarato introduced the term immaterial labour, by which he means "labor that produces the informational and cultural content of the commodity" (Lazzarato 1996, 133). Michael Hardt and Antonio Negri have popularized the term and define immaterial labour as labour "that creates immaterial products, such as knowledge, information, communication, a relationship, or an emotional response" (Hardt and Negri 2004, 108). For Hardt and Negri, it is the "key characteristic of immaterial labor to produce communication, social relations, and cooperation" (Hardt and Negri 2004, 113). Commonly produced knowledge would be exploited by capital: "The common [...] has become the locus of surplus value. Exploitation is the private appropriation of part or all of the value that has been produced as common" (Hardt and Negri 2004, 114). The Internet is a common information infrastructure. In its essence, it is part of the commons because all humans need to communicate in order to exist and reproduce themselves. But the actual reality of the Internet is that large parts of it are controlled by corporations and "immaterial" online labour is exploited and turned into surplus value in the form of the advertising-based Internet prosumer commodity. An alternative is what Hardt and Negri have termed the commonwealth, a society shaped by common ownership and co-operative production. The notions of commonwealth is also relevant for the Internet: "Freedom of the common is essential for production. As Internet and software practitioners and scholars often point out, access to the common in the network environment - common knowledges, common codes, common communication - is essential for creativity and growth" (Hardt and Negri 2009, 282). It is somewhat problematic to speak of "immaterial labour" because this implies that there are two substances of the world - matter and mind which cannot explain how the world is adequately grounded, and results in an idealistic and therefore in the end somewhat religious worldview (for a full critique see Fuchs and Zimmermann 2009). It might therefore be better to characterize online labour as (predominantly) knowledge labour. Nonetheless the core of Hardt's and Negri's argument, that social, communicative, and co-operative labour is exploited and transformed into surplus value in exploitation processes, is correct.

Tiziana Terranova (2004), using the autonomist concept of immaterial labour, describes the rise of a class that works for free in the "social fabric" of the internet: "Simultaneously voluntarily given and unwaged, enjoyed and exploited, free labour on the Net includes the activity of building Web sites, modifying software packages, reading and participating in mailing lists, and building virtual spaces" (Terranova $2004,74)$. Such activities are an expression of the collective productive capacities of immaterial labour. The concept of free labour has gained particular importance with the rise of web 2.0 in which capital is accumulated by providing free access. Accumulation here is dependent on the number of users and the content they provide. They are not paid for the content, but the more content and the more users join the more profit can be made by advertisements. Hence the users are exploited - they produce digital content for free in non-wage labour relationships.

Mark Coté and Jennifer Pybus (2007) have applied the concept of immaterial labour to web 2.0 activities in social networking platforms such as MySpace. They speak of immaterial labour 2.0, which would be a "more accelerated, intensified, and indeed inscrutable variant" (Coté and Pybus 2007, 89) of immaterial labour. Immaterial labour 2.0 would reflect a subjective turn of labour and be a specific form of the immaterial labour Hardt, Negri and Lazzarato speak of because it would be about "the active and ongoing construction of virtual subjectivities" (Coté and Pybus 2007, 90) and the production of surplus value by activities focuses on affects online and user-generated content. The approach by Coté and Pybus is important because it operates on a much more concrete level (web 2.0) than the one used by Hardt and Negri, but it shares with the latter the problematic implications from using the term "immaterial". The 
labour that characterizes web 2.0 systems is labour that is oriented on the production of affects, fantasy (cognitive labour) and social relations (communicative, co-operative labour) - it is like all labour material because it is activity that changes the state of real world systems. The difference between it and manual labour is that it doesn't primarily change the physical conditions of things, but instead the emotional and communicative aspects of human relations. It is also material in the sense that in its current forms it is ultimately to a certain extent oriented on the economy, subsumed under capital, and oriented towards producing economic profit. A better term than immaterial labour 2.0 hence is cognitive, communicative, and co-operative labour - informational labour (in contrast to manual labour, see Fuchs 2008 for this distinction).

I agree with Matteo Pasquinelli $(2009,2010)$ that an analysis and critique of the political economy of Google and other web 2.0 platforms is needed. I do now, however, agree with his form of analyzing the political economy of web 2.0 by employing the Marxian concept of rent. Pasquinelli's ideas are based on the autonomist approach. He argues that Google creates and accumulates value by its page rank algorithm and he says that Google's profit is a form of cognitive rent. Marx (1867) showed that technology never creates value, but is only a tool that is used by living human labour for creating labour. Therefore Pasquinelli advances a technological-deterministic assumption that the page rank algorithm creates value. Marx (1894) argued that rent is exchanged for land.

Marx (1894, Chapter 48) formulated the trinity formula that expresses the three aspects of the value of a commodity: profit (including interest), rent, wages. Profit is attached to capital, rent to land, and wage labour to labour. The three kinds of revenue are connected to the selling of labour power, land, and goods. Rent is obtained by lending land or real estates. It is not the direct result of surplus value production and human labour. No new product is created in the renting process. Rent indirectly stems from surplus value because capitalists take part of the surplus in order to rent houses, but it is created a a secondary process, in which surplus value is used for buying real estates. "First we have the use-value land, which has no value, and the exchange-value rent" (Marx 1894, 956). "Value is labour. So surplus-value cannot be earth" (Marx 1894, 954). Therefore the use of the category of rent to describe Internet practices and their outcomes means to assume that activities on the corporate Internet, such as surfing on Google or creating content on YouTube or Facebook, are not exploitative. The category of cognitive rent is not useful for a critical political economy of the Internet and web 2.0, the notion of the Internet prosumer commodity that is created by exploited knowledge labour is more feasible.

Søren Mørk Petersen (2008) analyzes how exploitation works on web 2.0. "The ease of copying and relocating content online as well as its network structure [...] makes it easy for capitalism to copy and reuse content produced by users into the sphere of a corporate site (reterritorialization)". As a result, "the architecture of participation turns into an architecture of exploitation and enclosure, transforming users into commodities that can be sold on the market". I agree with Peterson that there is exploitation online, but his paper is missing a clearer outline of the role of advertising as well as a grounding of the analysis in Marxian notions such as class, surplus value, or value.

Autonomist Marxism gives important impulses for theorizing online labour by providing categories such as the commons and pointing out the importance of the categories of exploitation and information labour. Many of the approaches are however too superficial and eclectic and not adequately grounded in the theory and categories of Marxian political economy and class theory (Fuchs 2010a). They are therefore not able to give a full picture of the role of information labour and the Internet in capitalism or end up in one-sided arguments that overestimate the resistance capacities and communist potentials of informational labour and do not see how ideologies can forestall societal change and the realization of potentials and how the Internet is used for reproducing domination (cf. Fuchs and Zimmermann 2009). 
The category of the prosumer commodity does not signify a democratization of the media towards a participatory or democratic system but rather the total commodification of human creativity. During much of the time that users spend online, they produce profit for large corporations like Google, News Corp. (which owns MySpace), or Yahoo! (which owns Flickr). Advertisements on the Internet are frequently personalized; this is made possible by surveilling, storing, and assessing user activities with the help of computers and databases. This is another difference from TV and radio, which provide less individualized content and advertisements due to their more centralized structure. But one can also observe a certain shift in the area of traditional mass media, as in the cases of pay per view, tele-votes, talkshows, and call-in TV and radio shows. In the case of the Internet, the commodification of audience participation is easier to achieve than with other mass media.

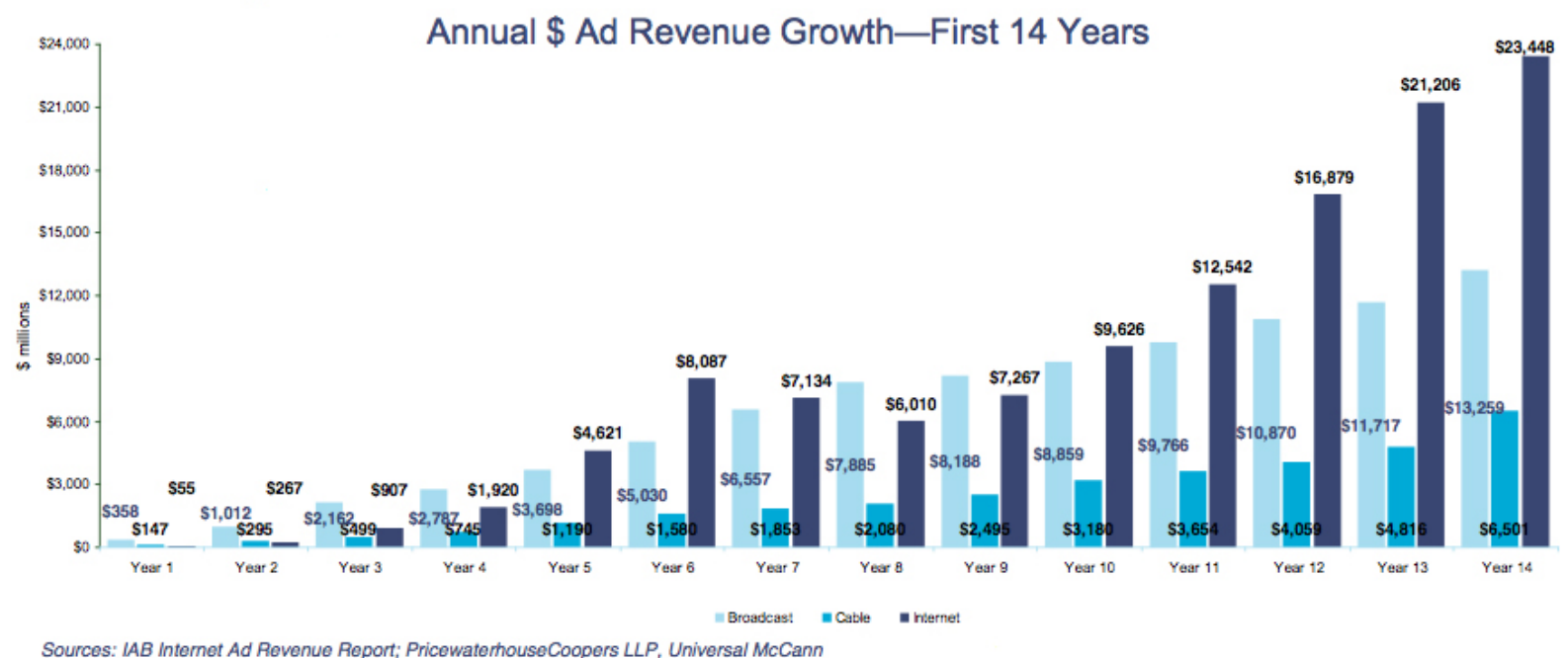

Figure 2: The growth of Internet advertising profits in the USA (IAB Internet Advertising Revenue Report 2008)

Figure 1.27 Advertising spending, by sector

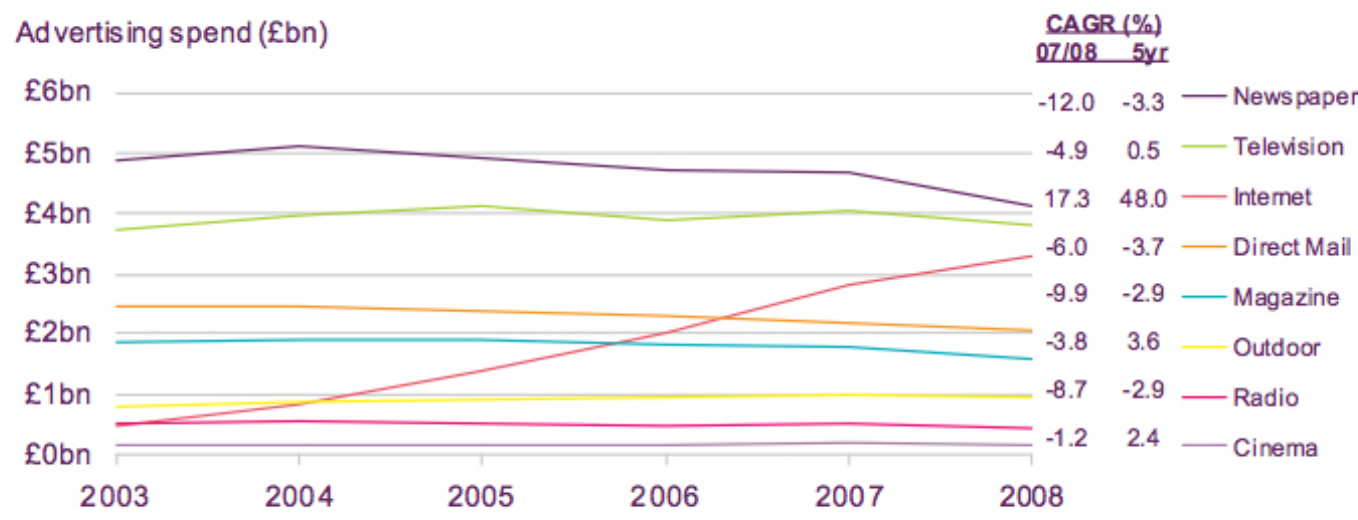

Source: Advertising Association statistics published by www.WARC.com

Figure 3: The growth of Internet advertising profits in the UK (Ofcom Communications Market Report 2009)

The importance of the prosumer commodity and extractive power as principles of contemporary web 2.0 is evidenced by the continuing absolute and relative rise of Internet advertising profits (see figures 2 and 3 ). In 2008, Internet advertising was the third-largest advertising market in the USA and the UK. Internet advertising profits were only exceeded in these two countries by advertising in newspapers and on TV (IAB Internet Advertising Revenue Report 2008: 14, Ofcom Communications Market Report 2009: 36). 
Surveillance in corporate web 2.0 is surveillance of prosumers who dynamically and permanently create and share user-generated content, browse profiles and data, interact with others, join and build communities, and co-create information. The corporate web platform operators and their third party advertising clients continuously monitor and record personal data and online activities, they store, merge, and analyze collected data. This allows them to create detailed user profiles and know about the personal interests and online behaviours of the users. Web platform operators sell the Internet prosumer as a commodity to advertising clients. Money is exchanged for access to user data that allows economic surveillance of the users. The exchange value of the Internet prosumer commodity is the money value that the operators obtain from their clients, its use value is the multitude of personal data and usage behaviour that is dominated by the commodity and exchange value form. The surveillance of the prosumers' permanently produced use values, i.e. personal data and interactions, by corporations allows targeted advertising that aims at luring the prosumers into consumption and at manipulating their desires and needs in the interest of corporations and the commodities they offer. Internet prosumers are first commodified by corporate platform operators who sell them to advertising clients and this results secondly in an intensified exposure to commodity logic. They are double objects of commodification: they are commodities themselves, and through this commodification their consciousness becomes permanently exposed to commodity logic while they are online in the form of advertisements. Most online time is advertising time. Two examples are Google and Facebook, which are in many countries the most accessed web platforms. Google makes use of users' search histories and many other personal data obtained from Google applications individuals use in order to present tailored advertisements to them. So the search results on Google will not only be ranked information pages, but pages framed and presented by commercial advertising related to the same topic. On Facebook, personal data, interests, interactions with others, information behaviour, and also the interaction with other websites is used for targeted advertising. So while you are using Facebook, it is not just you interacting with others and browsing profiles - all these activities are framed by advertisements presented to you. Such advertisements do not necessarily present consumers' needs because they are calculated, whereas needs are much more complex and spontaneous, and because they are distorted and only reflect marketing decisions and economic power relations. Much information by actors who do not have financial power, but is related to the same topic, is left out.

The Marxian cycle of capital accumulation allows us to distinguish between workplace surveillance, workforce surveillance, and consumer surveillance. On web 2.0, producers are consumers and consumers producers of information. Therefore, producer surveillance and consumer surveillance merge into web 2.0 prosumer surveillance. Web 2.0 surveillance of workplace and workforce (producer surveillance) is at the same time consumer surveillance and vice versa.

Dataveillance is the "systematic monitoring of people's actions or communications through the application of information technology" (Clarke 1988, 500). Clarke (1994) distinguishes between personal dataveillance that monitors the actions of one or more persons and mass dataveillance, where a group or large population is monitored in order to detect individuals of interest. In web 2.0, the boundaries between these two forms of surveillance become blurred: targeted advertising concerns the large mass of users of commercial web 2.0 platforms because they, by agreeing to the terms of use, agree in most cases to the surveillance of their personal data and their usage behaviour, but this surveillance is fine-tuned in order to detect and store the individual differences and to target each user with a separate mass of advertisings. Web 2.0 surveillance is therefore a form of mass personal dataveillance.

Manuel Castells (2009) characterizes web 2.0 communication as mass self-communication. Web 2.0 "is mass communication because it can potentially reach a global audience, as in the posting of a video on YouTube, a blog with RSS links to a number of web sources, or a message to a massive e-mail list. At the same time, it is self-communication because the production of the message is self-generated, the definition of the potential receiver(s) is self-directed, and the retrieval of specific messages or content from the 
World Wide Web and electronic networks is self-selected" (Castells 2009, 55). Web 2.0 surveillance is directed at large user groups who help to hegemonically produce and reproduce surveillance by providing user-generated (self-produced) content. We can therefore characterize web 2.0 surveillance as mass selfsurveillance.

Privacy statements are the legal mechanisms that guarantee that personalized advertising can be operated on web platforms. Users have hardly any choice not to agree; if they want to interact with others and make use of the technical advantages web 2.0 poses, they have to agree to these terms. Privacy statements are totalitarian mechanisms that are necessarily not democratically controlled by the users, but under the control of corporations. On the Internet, alternatives to commercial platforms are frequently not or hardly available because capital-rich actors can more easily create online platforms than those without, or with only little, capital, and platforms by well-known companies are also rich in symbolic capital so more users are attracted to them. Users can opt not to use a certain platform because they do not like its privacy policy, but this might result in communicative disadvantages, the loss of important private or professional contacts and opportunities, and therefore a deepening of the divide between the online-winners and the offline-losers.

So, for example, Facebook automatically uses targeted advertising. There is no way to opt out.

Facebook may use information in your profile without identifying you as an individual to third parties. We do this for purposes such as aggregating how many people in a network like a band or movie and personalizing advertisements and promotions so that we can provide you Facebook. We believe this benefits you. You can know more about the world around you and, where there are advertisements, they're more likely to be interesting to you.

(Facebook Privacy Policy, accessed on November 2, 2008).

We allow advertisers to select characteristics of users they want to show their advertisements to and we use the information we have collected to serve those advertisements. [...] We may receive information about whether or not you've seen or interacted with certain ads on other sites in order to measure the effectiveness of those ads. [...] Sometimes the advertisers who present ads on Facebook use technological methods to measure the effectiveness of their ads and to personalize advertising content.

(Facebook Privacy Policy, December 9, 2009).

MySpace also allows targeted personalized advertising that is automatically activated. Users can opt out, but doing so is very difficult. There is no menu setting in the privacy options that allows doing so, only a link in the privacy policy that users have to follow in order to opt out. MySpace states that

MySpace may use cookies and similar tools to customize the content and advertising you receive based on the Profile Information you have provided. Profile Information you provide in structured profile fields or questions (multiple choice questions like 'Marital Status,' 'Education' and 'Children') ('Structured Profile Information'), information you add to open-ended profile fields and questions (essay questions like 'About Me,' 'Interests' and 'Movies') ('Non-Structured Profile Information') and other non-PII about you may also be used to customize the online ads you encounter to those we believe are aligned with your interests.

(MySpace Privacy Policy, accessed on November 3, 2008).

Fernback and Papacharissi $(2007,716)$ conducted a discourse analysis of four web platform privacy statements and argue that "privacy statements are more often legal safeguards for companies rather than 
protectors of customer interests". "Each privacy statement initially assures consumers of a commitment to privacy and subsequently dismantles any true protection of consumer data. [...] these privacy statements pose virtually no restriction on businesses to profit excessively from the collection and use of consumer information" (Fernback and Papacharissi 2007, 730). Privacy statements of web site providers that process huge amounts of personal data are a typical expression of low state-controlled data protection standards ("self-regulation") that gives the freedom to companies to specify themselves how they want to treat personal data.

Oscar Gandy stated that "[T] $[$ he panoptic sort is a difference machine that sorts individuals into categories and classes on the basis of routine measurements. It is a discriminatory technology that allocates options and opportunities on the basis of those measures and the administrative models that they inform" (Gandy 1993, 15). It is a system of power and disciplinary surveillance that identifies, classifies, and assesses (Gandy 1993, 15). Prosumer commodification on web 2.0 is a form of panoptic sorting (Gandy 1993): it identifies the interests of users by closely surveilling their personal data and usage behaviour, it classifies them into consumer groups, and assesses their interests in comparison to other consumers and in comparison to available advertising that are then targeted at the users.

Foucault characterized surveillance in the following way: "He is seen, but he does not see; he is the object of information, never a subject in communication" (Foucault 1977, 200). With the rise of "web 2.0", the Internet has become a universal communication system, which is shaped by privileged data control by corporations that own most of the communication-enabling web platforms and by the state that can gain access to personal data by law. On the Internet, the separation between "objects of information" and "subjects in communication" that Foucault $(1977,200)$ described for historical forms of surveillance no longer exists. By being subjects of communication on the Internet, users make available personal data to others and continuously communicate over the Internet. These communications are mainly mediated by corporate-owned platforms, therefore the subjects of communication become objects of information for corporations and the state in surveillance processes. Foucault argues that power relations are different from relationships of communication, although they are frequently connected (Foucault 1994, 337). "Power relations are exercised, to an exceedingly important extent, through the production and exchange of signs", "relationships of communication [...] by modifying the field of information between partners, produce effects of power" (Foucault 1994, 338). In web 2.0, corporate and state power is exercised through the gathering, combination, and assessment of personal data that users communicate over the web to others, and the global communication of millions within a heteronomous society produces the interest of certain actors to exert control over these communications. In web 2.0, power relations and relationships of communication are interlinked. The users are producers of information (produsers, prosumers), but this creative communicative activity enables the controllers of disciplinary power to closely gain insights into the lives, secrets, and consumption preferences of the users.

Online labour is frequently connected to ideas like entertainment, play, and fun - traditionally the realm of leisure beyond wage labour. Contemporary capitalism and contemporary web 2.0 have brought about a blurring of the boundaries between production and consumption and therefore also between leisure time and work time. No clear separation is possible. Leisure, fun, play, and entertainment have become subsumed under capital - there is the exploitation and expropriation of the online commons of communication. Labour and play intersect, they create new forms of exploitation.

The main argument of this paper has been that web 2.0 is largely a commercial, profit-oriented machine that exploits users by commodifying their personal data and usage behaviour (web 2.0 prosumer commodity) and subjects these data to economic surveillance so that capital is accumulated with the help of targeted personalized advertising.

Postmodern surveillance scholars have in my view partly incorrectly interpreted Thomas Mathiesen's 
(1997, 2004) notion of the synopticon. Haggerty and Ericson interpret Mathiesen's notion of the synopticon as meaning “'bottom-up' forms of observation" (Haggerty and Ericson 2000/2007, 113). Hier (2003/2007, 118) argues that the surveillant assemblage brings about "a partial democratization of surveillance hierarchies". Mathiesen did not suggest that the synopticon brings about democratic surveillance, but that the panopticon and the synopticon are interlinked - "feed on each other" (Mathiesen 1997, 231) - and are structures of domination. For Mathiesen, the synopticon of the mass media "first of all directs and controls or disciplines our consciousness" (Mathiesen 1997, 230). He refers in this context to the critical theorists Enzensberger, Adorno, and Horkheimer and their culture industry theory. Mathiesen says that in the synopticon there is "an extensive system enabling the many to see and contemplate the few", whereas in the panopticon the few "see and supervise the many" (Mathiesen 1997, 219). There is a difference between seeing and supervizing, in Mathiesen's concept the many do not have the power to supervise the few, but the few have the power to supervise the many. The synopticon is a democratic system. Mathiesen does not see an optimistic alternative to Foucault's analysis in existence, but rather "things are much worse than Foucault imagined" (Mathiesen 1997, 231).

My analysis confirms the views of Thomas Mathiesen, who argues that the Internet is an undemocratic synopticon, in which the many observe the few, and that this does not bring about a "democratic system where everyone can participate in interaction" (Mathiesen 2004, 100). Mathieson explains:

The Internet becomes to a considerable extent a part of the synoptical system, in as much as it is, to a substantial degree, dominated by powerful economic agents - from newspapers and television agencies to owners having economic capital to invest in sales of lucrative merchandise, including pornography. To the same degree, the structure becomes characterised by a one-way flow, from the relatively few in control of economic capital, symbolic capital and technical know-how, to the many who are entertained or who buy the products" and are thereby silenced.

(Mathiesen 2004, 100).

He adds, "[A] basic feature of the Internet is, in other words, that it constitutes an interactive one-way medium, not an interactive two-way or multi-way medium. The agenda is set by those with economic, symbolic or technical capital" (Mathiesen 2004, 100f). The Internet is therefore in its corporate form for Mathiesen a "system of silencing".

Oscar Gandy argues that an alternative to opt-out solutions of targeted advertising are opt-in solutions that are based on the informed consent of consumers. When individuals

wish information or an information-based service, they will seek it out. It is not unreasonable to assume that individuals would be the best judge of when they are the most interested and therefore most receptive to information of a particular kind. Others with information to provide ought to assume that, unless requested, no information is desired. This would be the positive option. Through a variety of means, individuals would provide a positive indication that yes, I want to learn, hear, see more about this subject at this time. Individuals should be free to choose when they are ready to enter the market for information.

(Gandy 1993, 220).

He goes on to argues that "[T]he value in the positive option is its preservation of the individual's right to choose" (Gandy 1993, 221). Culnan and Bies also argue that opt-in is a form of procedural justice and a fair information practice. "Fair information practices are procedures that provide individuals with control over the disclosure and subsequent use of their personal information and govern the interpersonal treatment that consumers receive" (Culnan and Bies 2003, 330). Bellman et al. (2004) conducted a survey 
$(\mathrm{N}=534$ responses from 38 countries) that showed that the highest average agreement $(6.30,7$ point Likert scale, $1=$ strongly disagree, $7=$ =strongly agree) was achieved for the statement "web sites should not use personal information for any purpose unless it has been authorized by the individuals who provide the information". 79\% of US Internet users preferred opt-in solutions in 2000 (Pew Internet \& American Life Project Poll, May 2000). 85\% said in 2006 that it is very important that they can control who has access to their personal information (Pew Internet \& American Life Project Poll, December 2006). These results show that users consider opt-in strongly desirable and opt-out undesirable. Within capitalism, forcing corporations by state laws to implement opt-in mechanisms is certainly desirable, but at the same time it is likely that corporations will not consent to such policies because opt-in is likely to reduce the actual amount of surveilled and commodified user data significantly, which results in a drop of advertising profits. "Historically, members of information intensive industries have tended to be reactive, rather than pro-active, with regard to privacy policy" (Gandy 2003/2007, 296). Therefore capitalist interests are likely to naturally oppose the consumer interest of opt-in. Empirical studies confirm that given self-regulation, only a small portion of companies implements privacy policies that adhere to fair information practices (Federal Trade Commission 2000, Ryker et al. 2002). "Businesses have a great stake in access to individuals' personal information and tend to favor policies that allow self-regulation of privacy practices in engaging with customers" (Starke-Meyerring and Gurak 2007, 301).

\section{Conclusion}

In order to circumvent the large-scale surveillance of consumers, producers, and consumer-producers, movements and protests against economic surveillance are necessary. Kojin Karatani (2005) argues that consumption is the only space in capitalism where workers become subjects that can exert pressure by consumption boycotts on capital. I do not think that this is correct because strikes also show the subject position of workers that enables them to boycott production, to cause financial harm to capital, and to exert pressure in order to voice political demands. However, Karatani in my opinion correctly argues that the role of the consumer has been underestimated in Marxist theory and practice. The fact that in the contemporary media landscape media consumers become media producers who work and create surplus value shows the importance of the role of consumers in contemporary capitalism and of "the transcritical moment where workers and consumers intersect" (Karatani 2005, 21). For political strategies this brings up the actuality of an associationist movement that is "a transnational association of consumers/workers" (Karatani 2005, 295) that engages in "the class struggle against capitalism" of "workers qua consumers or consumers qua workers" (Karatani 2005, 294).

I recommend that critical citizens, critical citizens' initiatives, consumer groups, social movement groups, critical scholars, unions, data protection specialists/groups, consumer protection specialists/groups, critical politicians, and critical political parties observe closely the relationship of surveillance and corporations and document instances where corporations and politicians take measures that threaten privacy or increase the surveillance of citizens. Such documentation is most effective if it is easily accessible to the public. The Internet provides means for documenting such behaviour. It can help to watch the watchers and to raise public awareness. In recent years, corporate watch organizations that run online watch platforms have emerged. ${ }^{2}$

\footnotetext{
${ }^{2}$ Examples for corporate watch organizations are: CorpWatch Reporting (http://www.corpwatch.org), Transnationale Ethical Rating (http://www.transnationale.org), The Corporate Watch Project (http://www.corporatewatch.org), Multinational Monitor (http://www.multinationalmonitor.org), crocodyl: Collaborative research on corporations (http://www.crocodyl.org), Endgame Database of Corporate Fines (http://www.endgame.org/corpfines.html), Corporate Crime Reporter (http://www.corporatecrimereporter.com), Corporate Europe Observatory (http://www.corporateeurope.org), Corporate Critic Database (http://www.corporatecritic.org) .
} 
There are certainly limits of watchdog organizations and initiatives. They are generally civil society projects because it is unlikely that big corporations or governments support initiatives that tend to criticize corporations and governments with big amounts of money. Therefore such projects are frequently based on precarious, self-exploitative labour, and are confronted with a lack of resources such as money, activists, time, infrastructure, influence, and so forth. If political or economic institutions offer support, then there is a danger that they try to influence the activities of such projects, which can severely damage or limit the autonomy and critical facility of such projects. They seem to be trapped in an antagonism between resource precariousness and loss of autonomy that is caused by the fact that the control of resources is vital for having political influence in contemporary society and that resources in this very society are unequally distributed so that corporations and established political actors have much more power and influence than other actors. Given this situation, it would be a mistake not to try to organize citizens' initiatives, but one should bear in mind that due to the stratified character of capitalism it is more likely that such initiatives to organize will fail and remain unimportant than be successful in achieving their goals.

There are no easy solutions to the problem of civil rights limitations due to electronic surveillance. Opting out of existing advertising options is not a solution to the problem of economic and political surveillance. Even if users do opt out, media corporations will continue to collect and assess certain data on them, to sell the users as audience commodity to advertising clients, and to give personal data to the police. To try to advance critical awareness and to surveil corporate and political surveillers are important political moves for guaranteeing civil rights, but they will ultimately fail if they do not recognize that electronic surveillance is not a technological issue that can be solved by technological means or by different individual behaviours, but only by bringing about changes of society. Therefore the topic of electronic surveillance should be situated in the context of larger societal problems in public discourse.

Another recommendation is to create non-commercial, non-profit social networking platforms on the Internet. It is not impossible to create successful non-profit Internet platforms, as the example of Wikipedia, which is advertising-free, has free access, and is financed by donations, shows. But the difficulty is that social networking platforms have to store large amount of data, especially profile data that contain images, videos, etc., which requires tremendous server capacities. It is certainly easier and probably more efficient to organize such huge data storage endeavours in the form of profit-oriented businesses. But this orientation at the same time brings about the risk of extended and intensified electronic surveillance. I am not saying that non-commercial, non-profit platforms are devoid of this risk, but that there is a reduced likelihood that electronic surveillance for economic reasons will take place on such platforms and an increased likelihood that such platforms will try to protect its users from state surveillance. Within capitalism, it is certainly very difficult to try to organize such non-profit online alternatives because everything that is non-profit and non-commercial tends to be confronted by shortages of resources, which makes sustainable performance difficult. Trying to organize alternatives might be precarious and difficult, and is confronted with a high probability of potential failure. But the same time it might be the only constructive alternative to corporate control and corporate concentration processes in the Internet economy that tend to reinforce processes of economic and political electronic surveillance.

An example for an alternative social networking site is kaioo. It is operated by the Open Networx Initiative, which is a public trust created in 2007. The users of kaioo can discuss and edit the terms of use and privacy terms in a wiki. Kaioo is advertising-free and non-profit. Another example is the social networking project Diaspora. Its development was enabled by donations and spurred by the criticism of the corporate strategies of Facebook. The project's self-understanding is that it is a "privacy aware, personally controlled, do-it-all, open source social network" (Diaspora 2010).

An alternative Internet and alternative Internet platforms could provide the foundation for forms of online communication that are not based on economic surveillance. Slavoj Žižek argues in this context that "the 
digitalization of our daily lives, in effect, makes possible a Big Brother control in comparison with which the old Communist secret police supervision cannot but look like primitive child's play. Here, therefore, more than ever, one should insist that the proper answer to this threat is not retreat into islands of privacy, but an ever stronger socialization of cyberspace" (Žižek 2001, 256).

\section{Acknowledgement}

The research presented in this paper was conducted in the project "Social Networking Sites in the Surveillance Society", funded by the Austrian Science Fund (FWF): project number P 22445-G17. Project co-ordination by Dr. Christian Fuchs.

\section{References}

Attributor. 2008. Google Ad Server share now at 57\%. Microhoo less than 15\% market share. [Online] http://www.attributor.com/blog/google-ad-server-share-now-at-57-microhoo-less-than-15-market-share [Accessed $15 / 02 / 2010]$.

Andrejevic, Mark. 2007. iSpy: surveillance and power in the interactive era. Lawrence: University Press of Kansas.

Atton, Chris. 2004. An alternative Internet. Edinburgh: Edinburgh University Press.

Bellman, Steven, Eric J. Johnson, Stephen J. Kobrin, and Gerald L. Lohse. 2004. International differences in information privacy concerns: a global survey of consumers. The Information Society 20 (5): 313-324.

Brown, Felicity. 2006. Rethinking the role of surveillance studies in the critical political economy of communication. IAMCR Prize in Memory of Dallas W. Smythe 2006: http://www.iamcr.org/component/option,com_docman/task,doc download/gid,31/ [Accessed 28/08/2009].

Bruns, Axel. 2008. Blogs, Wikipedia, Second Life, and beyond. From production to produsage. New York: Peter Lang.

Castells, Manuel. 2009. Communication power. Oxford: Oxford University Press.

Clarke, Roger. 1988. Information technology and dataveillance. Communications of the ACM 31 (5): 498-512.

1994. Dataveillance: delivering '1984'. In Framing technology: society, choice and change, eds Lelia Green and Roger Guinery, 117-130. Sydney: Allen \& Unwin.

Coté, Mark and Jennifer Pybus. 2007. Learning to immaterial labour 2.0: MySpace and social networks. Ephemera 7 (1): 88-106.

Culnan, Mary J and Robert J. Bies. 2003. Consumer privacy. Balancing economic and justice considerations. Journal of Social Issues 59 (2): 323-342.

Diaspora, 2010. Join Diaspora. [Online] http://www.joindiaspora.com/ [Accessed 10/11/2010].

Federal Trade Commission. 2000. Privacy online: fair information practices in the electronic marketplace. [Online] http://www.ftc.gov/reports/privacy2000/privacy2000.pdf [Accessed 05/09/2009].

Fernback, Jan and Zizi Papacharissi. 2007. Online privacy as legal safeguard: the relationship among consumer, online portal, and privacy policies. New Media \& Society 9 (5): 715-734.

Foucault, Michel. 1977. Discipline \& Punish. New York: Vintage. - 1994. Power. New York: New Press.

Fuchs, Christian. 2008. Internet and society: social theory in the information age. New York: Routledge. 2009. Social networking sites and the surveillance society. A critical case study of the usage of studiVZ, Facebook, and MySpace by students in Salzburg in the context of electronic surveillance. Salzburg/Vienna: Research Group UTI. 2010a. Labor in informational capitalism and on the Internet. The Information Society 26 (3): 179-196.

2010b. Social Software and web 2.0: their sociological foundations and implications. In Handbook of research on web 2.0, 3.0, and X.0: technologies, business, and social applications, ed. San Murugesan, Volume II, 764-789. Hershey, PA: IGI-Global.

Fuchs, Christian and Rainer E. Zimmermann. 2009. Practical civil virtues in cyberspace: towards the utopian identity of civitas and multitudo. Munich Series in Design Science, Volume 5. Aachen: Shaker.

Fuchs, Christian, Wolfgang Hofkirchner, Matthias Schafranek, Celina Raffl, Marisol Sandoval, and Robert Bichler. 2010. Theoretical foundations of the web: cognition, communicaiton, and co-operation. Towards an understanding of web 1.0, 2.0, 3.0. Future Internet 2 (1): 41-59.

Gandy, Oscar H. 1993. The panoptic sort. A political economy of personal information. Boulder: Westview Press.

Google. 2010a. Google Privacy Policy. [Online] http://www.google.com/intl/en/privacypolicy.html [Accessed 09/07/2010].

Google. 2010b. Google Buzz Privacy Policy. [Online] http://www.google.com/buzz/help/privacy.html [Accessed 09/07/2010].

Google. 2010c. Google Buzz. [Online] http://www.google.com/buzz [Accessed 14/02/2010].

Habermas, Jürgen. 1981. Theorie des kommunikativen Handelns. 2 vols. Frankfurt/Main: Suhrkamp.

Haggerty, Kevin and Richard Ericson. 2000/2007. The surveillant assemblage. In The surveillance studies reader, eds Sean P. Hier and Josh Greenberg, 104-116. Berkshire: Open University Press.

Hardt, Michael and Antonio Negri. 2004. Multitude. New York: Penguin Press.

. 2009. Commonwealth. Cambridge, MA: Belknap Press.

Hier, Sean P. 2003/2007. Probing the surveillant assemblage: on the dialectics of surveillance practices as processes of social control. In The surveillance studies reader, Sean P. Hier and Josh Greenberg, 117-127. Berkshire: Open University Press.

Huffington Post. 2010. Google Drops Auto-Following, Adds Better Disable. [Online] http://www.huffingtonpost.com/2010/02/13/buzz-changes-google-drops_n 461656.html [Accessed 14/02/2010]. 
Jackson, T. 2010. A new Buzz start-up experience based on your feedback. [Online] http://gmailblog.blogspot.com/2010/02/newbuzz-start-up-experience-based-on.html [Accessed 14/02/2010].

Karatani, Kojin. 2005. Transcritique: On Kant and Marx. Cambridge, MA: MIT Press.

Lazzarato, Maurizio. 1996. Immaterial labor. In Radical thought in Italy, eds Paolo Virno and Michael Hardt, 133-146. Minneapolis, MN: University of Minnesota Press.

Lyon, David. 1994. The electronic eye. The rise of surveillance society. Cambridge: Polity.

Marx, Karl. 1867. Capital: Volume I. London: Penguin. 1885. Capital: Volume II. London: Penguin. 1894. Capital: Volume III. London: Penguin.

Mathiesen, Thomas. 1997. The viewer society: Michel Foucault's 'panopticon' revisited. Theoretical Criminology 1 (2): $215-234$. 2004. Panopticon and synopticon as silencing systems. In Silently silenced. Essays on the creation of acquiesence in modern society, 98-102. Winchester: Waterside Press.

Negri, Antonio. 1991. Marx beyond Marx. London: Pluto.

O’Reilly, Tim. 2005. Web 2.0: compact definition. [Online] http://radar.oreilly.com/archives/2005/10/web_20_compact definition.html [Accessed 02/12/ 2010]

Ogura, Toshimaru. 2006. Electronic government and surveillance-oriented society. In Theorizing surveillance, ed. David Lyon, 270-295. Portland, OR: Willan.

Pasquinelli, Matteo. 2009. Google's PageRank algorithm: a diagram of cognitive capitalism and the rentier of the common intellect. In Deep Search, eds Konrad Becker and Felix Stalder. London: Transaction Publishers.

- 2010. The ideology of free culture and the grammar of sabotage. In Education in the creative economy. Knowledge and learning in the age of innovation, ed. Daniel Araya and Michael Peters. New York: Peter Lang.

Petersen, Søren Mørk. 2008. Loser generated content. From participation to exploitation. First Monday 13 (3).

Ryker, Randy, Elizabeth Lafleur, Chris Cox and Bruce Mcmanis. 2002. Online privacy policies: an assessment of the fortune E50. Journal of Computer Information Systems 42 (4): 15-20.

Smythe, Dallas W. 1981/2006. On the audience commodity and its work. In Media and cultural studies, eds. Meenakshi G. Durham and Douglas. M. Kellner, 230-256. Malden, MA: Blackwell.

Stalder, Felix and Christine Mayer. 2009. The second index. Search engines, personalization and surveillance. In Deep Search, eds Konrad Becker and Felix Stalder. London: Transaction Publishers.

Starke-Meyerring, Doreen and Laura Gurak. 2007. Internet. In Encyclopedia of privacy, ed. William G. Staples, 297-310. Westport, CN: Greenwood Press.

Tapscott, Don and Anthony D. Williams. 2006. Wikinomics: how mass collaboration changes everything. London: Penguin.

Tech 24 Hours. 2009. Number of Gmail users worldwide as of Aug 2009. [Online] http://www.tech24hours.com/2009/09/numberof-gmail-users-worldwide-as-of.html [Accessed 14/02/ 2010].

Terranova, Tiziana. 2004. Network culture. Politics for the information age. London: Pluto Press.

Toffler, Alvin. 1980. The third wave. New York: Bantam.

YouTube. 2009. Google CEO Eric Schmidt on privacy. [Online] http://www.youtube.com/watch?v=A6e7wfDHzew [Accessed $14 / 02 / 2010]$.

YouTube. 2010. Google Buzz Launch Event. [Online] http://www.youtube.com/watch?v=JuThg91-4Nw [Accessed 15/02/2010].

Žižek, Slavoj. 2001. Did somebody say totalitarianism? London: Verso. 